\title{
Fellomyces ogasawarensis sp. nov. and Fellomyces distylii sp. nov., yeasts isolated from a plant in Japan
}

\author{
Makiko Hamamoto, Takashi Kuroyanagi and Takashi Nakase
}

Japan Collection of Microorganisms, The Institute of Physical and Chemical Research (RIKEN), Wako, Saitama 351-01, Japan
Author for correspondence: Makiko Hamamoto. Tel: +81484621111 ext. 5113. Fax: +81 484645651 . e-mail: hamamoto@ulmus.riken.go.jp
Keywords: new Fellomyces species, 18S rRNA gene sequencing

\begin{abstract}
Fellomyces ogasawarensis and Fellomyces distylii, new yeast species isolated from a dead leaf of a plant (Distylium lepidotum Nakai, family Hamamelidaceae) collected in the Ogasawara Islands, isolated islands in the Pacific Ocean about $1000 \mathrm{~km}$ south of Japan, are described. The phylogenetic relationship of $F$. ogasawarensis and $F$. distylii with other members of the genus Fellomyces was estimated from 185 rRNA gene sequence analysis. The type strain of F. ogasawarensis is strain OK-81 (= JCM 9861) and that of $F$. distylii is strain OK-83 (= JCM 9862).
\end{abstract}

\section{INTRODUCTION}

The genus Fellomyces was established by Yamada \& Banno based on a single species, Fellomyces polyborus (16), which was originally described as Sterigmatomyces polyborus (8). This genus can be distinguished from Sterigmatomyces by the production of conidia, which are freed by an end-break in the sterigmata, and the presence of $\mathrm{Q}_{10}$ as the major ubiquinone isoprenologue (16). Four species, Fellomyces fuzhouensis, Fellomyces horovitziae, Fellomyces penicillatus and Fellomyces polyborus, are currently recognized in the genus Fellomyces (1).

In the course of a survey of basidiomycetous yeasts living on the leaves of plants in the Ogasawara Islands, isolated islands in the Pacific Ocean south of Japan, two strains of stalked-conidium-forming yeasts were isolated. Comparison of the phenotypic properties of the new isolates and their levels of DNA hybridization with Fellomyces species revealed that these strains represented two new species of the genus Fellomyces. The names Fellomyces ogasawarensis and Fellomyces distylii are proposed for these yeasts.

\section{METHODS}

Yeast isolation and cultivation. A sample of a dead leaf of Distylium lepidotum Nakai (family Hamamelidaceae) was collected on Ani-jima Island of the Ogasawara Islands, Japan. The procedure used for yeast isolation and purification has been described previously $(5,7)$. Strains were

The DDBJ accession numbers for the 18S rRNA gene sequences determined in this study are listed in Table 1. grown on YM agar (Difco) at $25^{\circ} \mathrm{C}$. F. fuzhouensis $\mathrm{JCM}$ $7367^{\mathrm{T}}(\mathrm{T}=$ type strain $), F$. horovitziae $\mathrm{JCM} 8358^{\mathrm{T}}, F$. penicillatus JCM $6907^{\mathrm{T}}$ and $F$. polyborus $\mathrm{JCM} 6908^{\mathrm{T}}$ were used for taxonomic comparisons. All strains were grown at $25^{\circ} \mathrm{C}$ in YM broth (Difco), harvested by centrifugation, and washed with saline/EDTA buffer $(0 \cdot 15 \mathrm{M} \mathrm{NaCl}, 1 \mathrm{M}$ EDTA; $\mathrm{pH} 8.0$ ) for extraction of ubiquinone and nuclear DNA.

Physiological and chemotaxonomic characteristics. The isolates were characterized phenotypically by the methods currently used in yeast taxonomy (15) with some modifications. Assimilation of nitrogen compounds was examined on solid media with starved inoculum as described by Nakase \& Suzuki (6). The vitamin requirements were investigated according to Komagata \& Nakase (4). The maximum growth temperature was determined in YM broth (Difco) by using metal block baths.

Sugars in the whole cell were analysed by HPLC after hydrolysis as described previously (12). Ubiquinones were extracted and purified by the method of Yamada \& Kondo (17) with slight modifications and determined by HPLC as described previously (3).

Nucleic acid analyses. DNA extraction, purification and reassociation were performed by the procedure of Hamamoto \& Nakase (3). Nuclear DNA base compositions were determined by HPLC as described by Tamaoka \& Komagata (13), with a minor modification (3).

The following oligodeoxynucleotides were synthesized on the basis of conserved regions at the $5^{\prime}$ and $3^{\prime}$ termini of eukaryotic 18S rRNAs with 12- and 13-nucleotide-long tails (enclosed in brackets), respectively, for use by the PCRDirect Cloning System (Clontech): 5'-[CTCGCTCGCCCA]ATCTGGTTGATCCTGCCAGT-3' and 5'-[CTGGTTCGGCCCA]GATCCTTCCGCAGGTTCACC-3'. The DNA of the 18S rRNA coding gene was amplified by using PCR (9) with a Taq DNA polymerase (Takara) and the 
Table 1. Yeast strains compared in this study and their small-subunit rRNA gene sequence accession numbers

\begin{tabular}{|c|c|c|}
\hline Species & Strain* & $\begin{array}{c}\text { DDBJ, EMBL } \\
\text { and/or GenBank } \\
\text { accession no. }\end{array}$ \\
\hline Athelia bombacina & ATCC 20629 & M55638 \\
\hline Auricularia auricula-judae & UC 1475109 & L22254 \\
\hline Bulleromyces albus & MUCL $30301^{\mathrm{T}}$ & X60179 \\
\hline Calocera cornea & UC 1475111 & L22256 \\
\hline Candida albicans & Unknown & X53497 \\
\hline Cryptococcus albidus & $\mathrm{JCM} 2334^{\mathrm{T}}$ & D31655 \\
\hline Cystofilobasidium capitatum & IAM $13521^{\mathrm{T}}$ & D12801 \\
\hline Dacrymyces chrysospermus & UC 1475112 & L22257 \\
\hline Fellomyces distylii & $\mathrm{JCM} 9862^{\mathrm{T}}$ & $\mathrm{AB} 001036 \dagger$ \\
\hline Fellomyces fuzhouensis & $\mathrm{JCM} 7367^{\mathrm{T}}$ & $\mathrm{AB} 001032 \dagger$ \\
\hline Fellomyces horovitziae & $\mathrm{JCM} 8358^{\mathrm{T}}$ & $\mathrm{AB} 001033 \uparrow$ \\
\hline Fellomyces ogasawarensis & $\mathrm{JCM} 9861^{\mathrm{T}}$ & $\mathrm{AB} 001035 \dagger$ \\
\hline Fellomyces penicillatus & JCM $6907^{\mathrm{T}}$ & $\mathrm{AB} 001034 \uparrow$ \\
\hline Fellomyces polyborus & $\mathrm{JCM} 6908^{\mathrm{T}}$ & D64117 \\
\hline Fibulobasidium inconspicuum & JCM 6898 & D64123 \\
\hline Filobasidium floriforme & IAM 14212 & D13460 \\
\hline Filobasidiella neoformans & IAM 14211 & D12804 \\
\hline Kockovaella thailandica & JCM 7824 & D64133 \\
\hline Kurtzmanomyces nectairei & $\mathrm{JCM} 6906^{\mathrm{T}}$ & D64122 \\
\hline Mixia osmundae & IFO 32408 & D14163 \\
\hline Mrakia frigida & IAM $14136^{\mathrm{T}}$ & D12802 \\
\hline Neurospora crassa & Unknown & X04971 \\
\hline Pseudohydnum gelatinosum & UC 1475114 & L22260 \\
\hline Saccharomyces cerevisiae & Unknown & M27607 \\
\hline Spongipellis unicolor & Unknown & M59760 \\
\hline Sporidiobolus johnsonii & Unknown & L22261 \\
\hline Sporobolomyces roseus & Unknown & X60181 \\
\hline Sterigmatomyces halophilus & JCM $6905^{\mathrm{T}}$ & D64119 \\
\hline Sterigmatosporidium polymorphum & JCM $6902^{\mathrm{T}}$ & D64120 \\
\hline Thanatephorus cucumeris & Unknown & M92990 \\
\hline Tilletia caries & Unknown & U00972 \\
\hline Tilletiopsis washingtonensis & $\mathrm{JCM} 8362^{\mathrm{T}}$ & D83192 \\
\hline Tremella foliacea & Unknown & L22262 \\
\hline Tremella globospora & Unknown & U00976 \\
\hline Tremella moriformis & Unknown & U00977 \\
\hline Trichosporon cutaneum & MUCL $30308^{\mathrm{T}}$ & X60182 \\
\hline Tsuchiyaea wingfieldii & JCM $7368^{\mathrm{T}}$ & D64121 \\
\hline Udeniomyces piricola & JCM $2958^{\mathrm{T}}$ & D31659 \\
\hline Ustilago hordei & Unknown & U00973 \\
\hline Ustilago maydis & Unknown & X62396 \\
\hline Xanthophyllomyces dendrorhous & JCM $9042^{\mathrm{T}}$ & D31656 \\
\hline
\end{tabular}

*IAM, IAM Culture Collection, Tokyo, Japan; JCM, Japan Collection of Microorganisms, Saitama, Japan; MUCL, Mycothèque de l'Université Catholique, Louvain-la Neuve, Belgium; UC, University Herbarium, University of California, Berkeley, USA. T, Type strain.

$\uparrow$ Sequence determined in this study.

oligonucleotides described above for primers. The PCR products were cloned directly in the linearized pDIRECT vector (Clontech) and the double-stranded DNA templates for sequencing were prepared according to the directions of the manufacturer. Sequencing was performed by using the Pharmacia Autocycle Sequencing kit (Taq DNA polymerase) as described by Suh et al. $(10,11)$.
Analysis of sequence data. The yeast strains which were used for the phylogenetic analysis are listed in Table 1 . The five $18 \mathrm{~S}$ rDNA sequences which we determined were aligned with the sequences of 36 other basidiomycetes and ascomycetes retrieved from the GenBank and DDBJ libraries by using the multiple-alignment program CLUSTAL w (14). The alignments were manually adjusted. An unrooted phylo- 
genetic tree was constructed by using the NEIGHBOR program contained in the PHYLIP package, version 3.5 (2). The confidence values of branches were determined by performing a bootstrap analysis in which 1000 replicates were used (2).

\section{RESULTS AND DISCUSSION}

Two strains, OK-81 and OK-83, were characterized by the production of conidia, which were freed by an endbreak in the sterigma, the lack of ballistoconidia, the presence of xylose in the whole cells, and the presence of $\mathrm{Q}_{10}$ as the major ubiquinone isoprenologue. On the basis of these results, these two isolates were assigned to the genus Fellomyces.

Strains OK-81 and OK-83 differ from the four known species of Fellomyces in nuclear DNA base composition, and exhibit low levels of DNA relatedness to the type strains of the known species and also between each other (Table 2). Apparently, strains OK-81 and
OK-83 represent two distinct new species of the genus Fellomyces. Table 3 shows the phenotypic characteristics among six species of the genus Fellomyces.

The names Fellomyces ogasawarensis and Fellomyces distylii have been given to these new species and they are described below.

\section{Latin diagnosis of Fellomyces ogasawarensis sp. nov.}

In liquid YM post dies $3\left(25^{\circ} \mathrm{C}\right)$, cellulae sphaericae vel ovoideae $(2.0-3.0 \times 4 \cdot 0-8.0 \mu \mathrm{m})$. Conidia singula in apicem cylindraceorum sterigmatum formata et ad apicem sterigmatis sine projectione liberata. Post 1 mensem sedimentum et pelliculum formantur. Cultura in agaro $Y M$ post 1 mensem $\left(25^{\circ} \mathrm{C}\right)$, albo-isabellinus, rugosa, non nitida, margine integer. Pseudohyphae nullae. Ballistospoae non formantur. Fermentaio nulla. Glucosum, galactosum, L-sorbosum, saccharosum,

Table 2. Levels of DNA complementarity for Fellomyces species

\begin{tabular}{|c|c|c|c|c|c|c|c|c|}
\hline \multirow[t]{2}{*}{ Species } & \multirow[t]{2}{*}{ Strain* } & \multirow{2}{*}{$\begin{array}{c}\text { G }+\mathbf{C} \\
\mathrm{mol} \% \uparrow\end{array}$} & \multicolumn{6}{|c|}{ Percentage relative binding of DNA from: } \\
\hline & & & $\begin{array}{r}\text { JCM } 9861 \\
(=\text { OK-81) }\end{array}$ & $\begin{array}{r}\text { JCM } 9862 \\
(=\text { OK-83) }\end{array}$ & JCM 7367 & JCM 8358 & JCM 6907 & JCM 6908 \\
\hline F. ogasawarensis & $\begin{array}{l}\mathrm{JCM} 9861^{\mathrm{T}} \\
(=\text { OK-81) }\end{array}$ & $53 \cdot 3$ & 100 & 24 & 16 & 12 & 3 & 10 \\
\hline F. distylii & $\begin{array}{l}\text { JCM } 9862^{\mathrm{T}} \\
(=\text { OK-83) }\end{array}$ & $51 \cdot 4$ & 14 & 100 & 13 & 10 & 2 & 7 \\
\hline F. fuzhouensis & $\mathrm{JCM} 7367^{\mathrm{T}}$ & $54 \cdot 6$ & 3 & 6 & 100 & & & \\
\hline F. horovitziae & $\mathrm{JCM} 8358^{\mathrm{T}}$ & $52 \cdot 1$ & 3 & 5 & & 100 & & \\
\hline F. penicillatus & $\mathrm{JCM} 6907^{\mathrm{T}}$ & $47 \cdot 9$ & 2 & 5 & & & 100 & \\
\hline F. polyborus & $\mathrm{JCM} 6908^{\mathrm{T}}$ & $48 \cdot 2$ & 2 & 7 & & & & 100 \\
\hline
\end{tabular}

* $\mathrm{T}$, Type strain.

$\uparrow$ Determined by HPLC in this study.

Table 3. Characteristics differentiating $F$. ogasawarensis and $F$. distylii from known species

+ , Positive; - , negative

\begin{tabular}{|c|c|c|c|c|c|c|}
\hline & F. ogasawarensis & F. distylii & F. fuzhouensis & F. horovitziae & F. penicillatus & F. polyborus \\
\hline $\mathrm{G}+\mathrm{C} \mathrm{mol} \%$ & $53 \cdot 3$ & $51 \cdot 4$ & $54 \cdot 6$ & $52 \cdot 1$ & $47 \cdot 9$ & $48 \cdot 2$ \\
\hline \multicolumn{7}{|l|}{ Assimilation of: } \\
\hline Soluble starch & + & + & + & - & + & + \\
\hline L-Rhamnose & + & - & + & - & + & + \\
\hline Ethanol & - & - & + & - & - & - \\
\hline Erythritol & - & + & + & - & + & + \\
\hline Galactitol & + & + & + & - & + & + \\
\hline D-Mannitol & + & + & + & - & + & + \\
\hline Glucono- $\delta$-lactone & + & + & + & + & - & + \\
\hline 2-Ketogluconic acid & + & + & + & - & + & + \\
\hline DL-Lactic acid & + & - & $+1-$ & - & $+1-$ & - \\
\hline Inositol & - & - & + & - & + & + \\
\hline
\end{tabular}




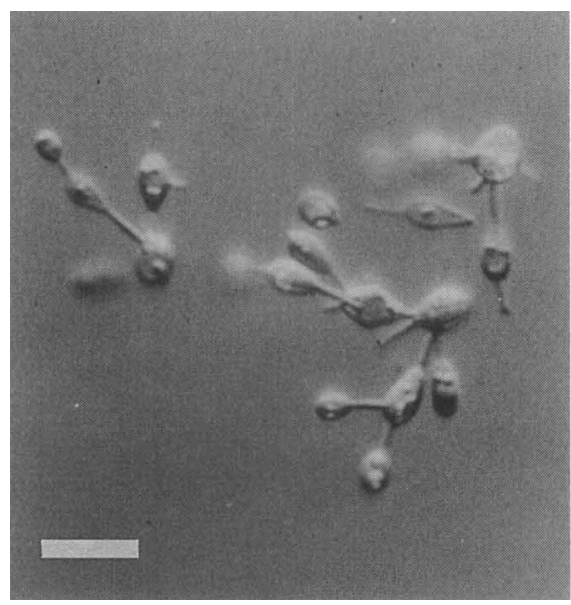

Fig. 1. F. ogasawarensis JCM 9861. Conidia in the sterigmata produced on $\mathrm{YM}$ agar after $5 \mathrm{~d}$ at $25^{\circ} \mathrm{C}$. Bar, $10 \mu \mathrm{m}$.

maltosum, cellobiosum, trehalosum, lactosum, melibiosum, raffinosum, melezitosum, amylum solubile, D-xylosum, L-arabinosum, D-arabinosum, D-ribosum, L-rhamnosum, glycerolum, ribitolum, galactitolum, $D$-mannitolum, $D$-glucitolum, salicinum, glucono- $\delta$ lactonum, acidum 2-ketogluconicum, acidum 5-ketogluconicum, acidum DL-lacticum, acidum succinicum, acidum citricum, acidum D-glucuronicum et acidum D-galacturonicum assimilantur, at non inulinum, ethanolum, erythritolum, methyl $\alpha$-D-glucosidum nec inositolum. Lysinum assimilatur at non kalium nitricum, natrium nitrosum, ethylaminum nec cadaverinum. Maxima temperatura crescentiae: $28-29^{\circ} \mathrm{C}$. $\mathrm{Ad}$ crescentiam thiaminum necessarium est. Materia amyloidea iodophila non formatur. Ureum hydrolysatur. Diazonium caeruleum B: positivum. Proportio molaris guanini + cytosini in acido deoxyribonucleinico: 53.3 mol\% (per HPLC). Ubiquinonum majus: $Q_{10}$. Xylosum in cellulis praesens.

Holotypus ex folio Distylium lepidotum, Japan, $X$, 1994, T. Nakase, JCM 9861 (originaliter ut OK-81) conservatur in collectionibus culturarum quas 'Japan Collection of Microorganisms', Wako, Saitama sustentat.

\section{Description of Fellomyces ogasawarensis sp. nov.}

Fellomyces ogasawarensis (o.ga.sa.war.en'sis. M.L. adj. ogasawarensis referring to Ogasawara, the remote islands in the Pacific Ocean of Japan where the type strain was isolated).

After growth in YM broth (Difco) for $3 \mathrm{~d}$ at $25^{\circ} \mathrm{C}$, the cells are spherical to ovoid $(2 \cdot 0-3.0 \times 4 \cdot 0-8.0 \mu \mathrm{m})$ and produce one or more sterigmata, each giving rise to a single conidium. The conidium is freed without forceful ejection by an end-break in the sterigma (Fig. 1). A sediment and a hydrophobic pellicle are formed after 1 month. After growth on YM agar (Difco) at $25^{\circ} \mathrm{C}$ for $3 \mathrm{~d}$, the streak culture is yellowish white. After 1

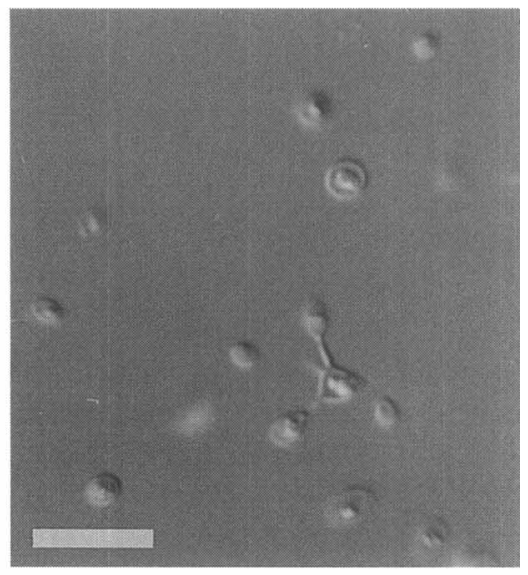

Fig. 2. F. distylii JCM 9862 . Conidia in the sterigmata produced on YM agar after $5 \mathrm{~d}$ at $25^{\circ} \mathrm{C}$. Bar, $10 \mu \mathrm{m}$.

month, the streak culture is yellow-sienna, wrinkled, dull, and has an entire margin. On Dalmau plate cultures on corn meal agar after $10 \mathrm{~d}$ at $25^{\circ} \mathrm{C}$ no true mycelia and pseudomycelia develop. No ballistoconidia are formed. Does not ferment D-glucose. Assimilates D-glucose, galactose, L-sorbose, sucrose, maltose, cellobiose, trehalose, lactose, melibiose, raffinose, melezitose, soluble starch, D-xylose, L-arabinose, D-arabinose, D-ribose, L-rhamnose, glycerol, ribitol, galactitol, D-mannitol, D-glucitol, salicin, glucono- $\delta$ lactone, 2-ketogluconic acid, 5-ketogluconic acid, DLlactic acid, succinic acid, citric acid, D-glucuronic acid and D-galacturonic acid. Does not assimilate the carbon in inulin, ethanol, erythritol, methyl $\alpha$-Dglucoside and inositol. Does not assimilate the following nitrogen sources: nitrate, nitrite, ethylamine and cadaverine. Assimilation of L-lysine is positive. Maximum growth temperature is $28-29^{\circ} \mathrm{C}$. Thiamin is required for growth. Growth does not occur on $50 \%$ (w/w) glucose-yeast extract agar. No starch-like substance is produced. Does not liquefy gelatin. Growth occurs in the presence of 100 p.p.m. cycloheximide. Urease is positive. The diazonium blue $\mathrm{B}$ reaction is positive.

The $\mathrm{G}+\mathrm{C}$ content of the nuclear DNA is $53 \cdot 3 \mathrm{~mol} \%$, as determined by HPLC (Table 2). The major ubiquinone is $\mathrm{Q}_{10}$. Xylose is present in the whole cells.

The type strain of $F$. ogasawarensis, strain OK-81, was isolated from a leaf of Distylium lepidotum Nakai in the Ogasawara Islands, Japan. This strain has been deposited in the Japan Collection of Microorganisms, Saitama, Japan, as JCM 9861.

\section{Latin diagnosis of Fellomyces distylii sp. nov.}

In liquid $Y M$ post dies $3\left(25^{\circ} \mathrm{C}\right)$, cellulae sphaericae vel ovoideae $(2 \cdot 0-3.0 \times 4 \cdot 0-6.0 \mu \mathrm{m})$. Conidia singula in apicem cylindraceorum sterigmatum formata et ad apicem sterigmatis sine projectione liberata. Post 1 mensem sedimentum et pelliculum formantur. Cultura in agaro 


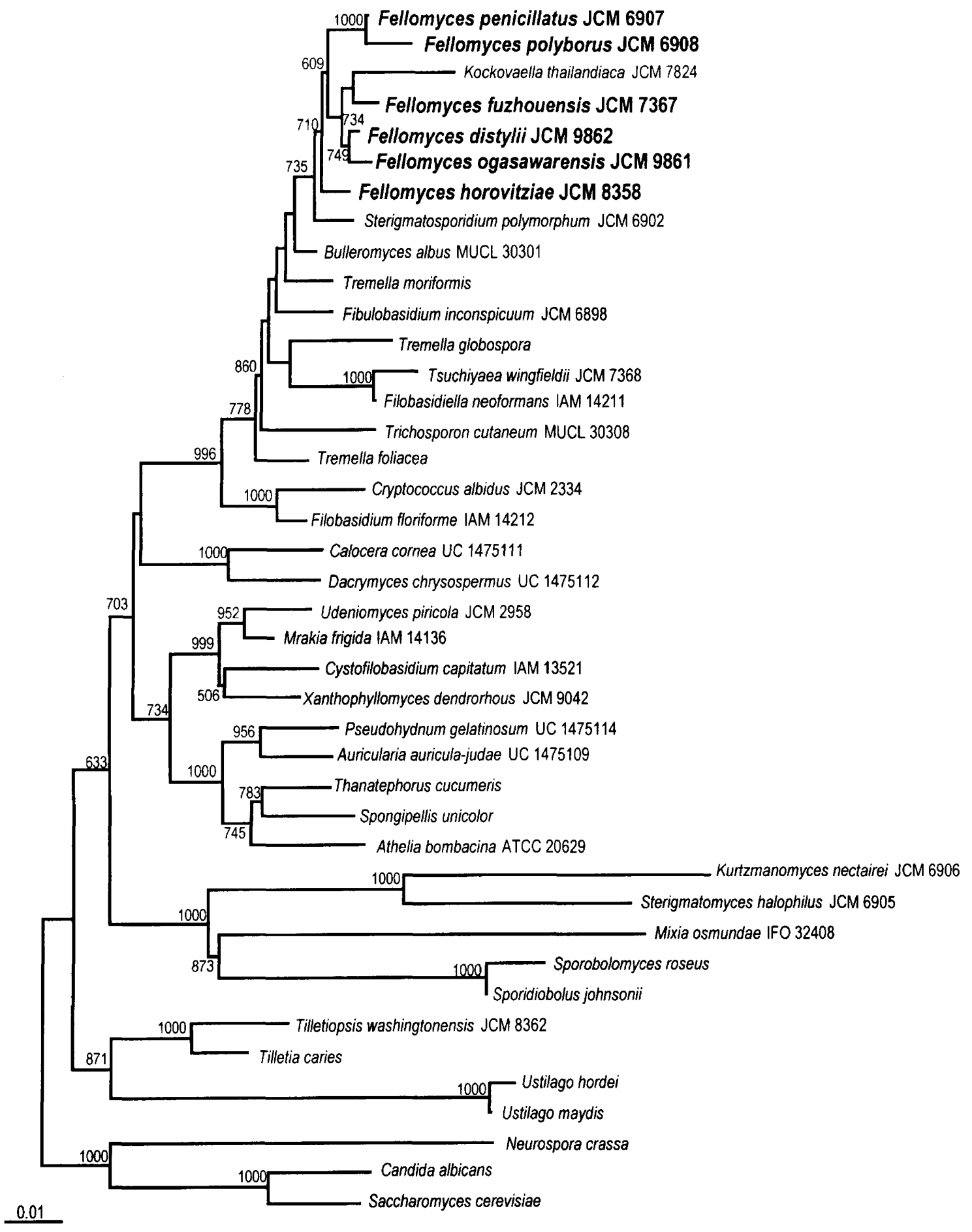

Fig. 3. Phylogenetic tree of the species of the genus Fellomyces and related taxa. Trees was constructed as described in the text. Bootstrap values greater than $50 \%$ are shown. The bar indicates the distance corresponding to 1 base change per 100 nucleotide positions.

YM post 1 mensem $\left(25^{\circ} \mathrm{C}\right)$, isabellinus, butyrosa, glabra, non nitida, margine integer. Pseudohyphae nullae. Ballistospoae non formantur. Fermentaio nulla. Glucosum, galactosum, L-sorbosum, saccharosum, maltosum, cellobiosum, trehalosum, lactosum, melibiosum, raffinosum, melezitosum, amylum solubile, D-xylosum,
L-arabinosum, D-arabinosum, D-ribosum, glycerolum, erythritolum, ribitolum, galactitolum, $D$-mannitolum, $D$ glucitolum, salicinum, glucono- $\delta$-lactonum, acidum 2ketogluconicum, acidum 5-ketogluconicum, acidum succinicum, acidum citricum, acidum D-glucuronicum et acidum D-galacturonicum assimilantur, at non inulinum, 
L-rhamnosum, ethanolum, methyl $\alpha$-D-glucosidum, acidum DL-lacticum nec inositolum. Lysinum assimilatur at non kalium nitricum, natrium nitrosum, ethylaminum nec cadaverinum. Maxima temperatura crescentiae: $27-28^{\circ} \mathrm{C}$. Ad crescentiam thiaminum necessarium est. Materia amyloidea iodophila non formatur. Ureum hydrolysatur. Diazonium caeruleum B: positivum. Proportio molaris guanini + cytosini in acido deoxyribonucleinico: $51.4 \mathrm{~mol} \%$ (per HPLC). Ubiquinonum majus: $Q_{10}$. Xylosum in cellulis praesens.

Holotypus ex folio Distylium lepidotum, Japan, $X$, 1994, T. Nakase, JCM 9862 (originaliter ut OK-83) conservatur in collectionibus culturarum quas 'Japan Collection of Microorganisms', Wako, Saitama sustentat.

\section{Description of Fellomyces distylii sp. nov.}

Fellomyces distylii (di'sty.li.i. M.L. gen. n. distylii of Distylium [Distylium lepidotum], the plant from which the type strain was isolated).

After growth in YM broth (Difco) for $3 \mathrm{~d}$ at $25^{\circ} \mathrm{C}$, the cells are spherical to ovoid $(2.0-3.0 \times 4.0-6.0 \mu \mathrm{m})$ and produce one or more sterigmata, each giving rise to a single conidium. The conidium is freed without forceful ejection by an end-break in the sterigma (Fig. 2). A sediment and a hydrophobic pellicle are formed after 1 month. After growth on YM agar (Difco) at $25^{\circ} \mathrm{C}$ for $3 \mathrm{~d}$, the streak culture is yellowish white. After 1 month, the streak culture is sienna, butyrous, smooth, dull, and has an entire margin. On Dalmau plate cultures on corn meal agar after $10 \mathrm{~d}$ at $25^{\circ} \mathrm{C}$ no true mycelia and pseudomycelia develop. No ballistoconidia are formed. Does not ferment D-glucose. Assimilates D-glucose, galactose, L-sorbose, sucrose, maltose, cellobiose, trehalose, lactose, melibiose, raffinose, melezitose, soluble starch, D-xylose, L-arabinose, D-arabinose, D-ribose, glycerol, erythritol, ribitol, galactitol, D-mannitol, D-glucitol, salicin, glucono- $\delta$ lactone, 2-ketogluconic acid, 5-ketogluconic acid, succinic acid, citric acid, D-glucuronic acid and Dgalacturonic acid. Does not assimilate the carbon in inulin, L-rhamnose, ethanol, methyl $\alpha$-D-glucoside, DL-lactic acid and inositol. Does not assimilate the following nitrogen sources: nitrate, nitrite, ethylamine and cadaverine. Assimilation of L-lysine is positive. Maximum growth temperature is $27-28^{\circ} \mathrm{C}$. Thiamin is required for growth. Growth does not occur on $50 \%$ (w/w) glucose-yeast extract agar. No starch-like substance is produced. Does not liquefy gelatin. Growth occurs in the presence of 100 p.p.m. cycloheximide. Urease is positive. The diazonium blue $\mathrm{B}$ reaction is positive. The $\mathrm{G}+\mathrm{C}$ content of the nuclear DNA is $51.4 \mathrm{~mol} \%$, as determined by HPLC (Table 2). The major ubiquinone is $\mathrm{Q}_{10}$. Xylose is present in the whole cells.

The type strain of $F$. distylii, strain OK-83, was isolated from a leaf of Distylium lepidotum Nakai in the Ogasawara Islands, Japan. The strain has been deposited in the Japan Collection of Microorganisms, Saitama, Japan, as JCM 9862.

\section{Phylogenetic relatedness of $F$. ogasawarensis and F. distylii}

We determined almost complete $18 \mathrm{~S}$ rDNA sequences of the two new species and three known species of Fellomyces, $F$. fuzhouensis, $F$. horovitziae and $F$. penicillatus. The trees in Fig. 3 were constructed, using the NEIGHBOR program, from the data sets aligned by CLUSTAL $\mathrm{W}$ on 1501 18S rDNA sites (14). The percentage of bootstraps was derived from 1000 resamplings in the neighbour-joining tree. Values that were greater than $50 \%$ are shown. The branch comprising the species of the genus Fellomyces includes Kockovaella thailandica and Sterigmatosporidium polymorphum, which also known as stalked-conidiumforming yeasts. Our evolutionary tree indicates that the species of the genus Fellomyces belong to the Tremellomycetidae lineage.

Two strains from a dead leaf of a plant (Distylium lepidotum Nakai) fit the description of the genus Fellomyces, and they are described here as two new species, $F$. ogasawarensis and $F$. distylii. As a result of our description of two new species, a total of six species should be approved in the genus Fellomyces. Strains of this genus have been isolated from various sources, including animals, plants, and tunnels of some insects.

\section{ACKNOWLEDGEMENTS}

We thank Dr Toyozo Sato, Shikoku National Agricultural Experiment Station, Japan, for kindly supplying plant materials collected in the Ogasawara Islands.

\section{REFERENCES}

1. Barnett, J. A., Payne, R. W. \& Yarrow, D. (1990). Yeasts: Characteristics and Identification, 2nd edn. Cambridge: Cambridge University Press.

2. Felsenstein, J. (1993). PHYLIP : phylogenetic inference package, version 3.5. University of Washington, Seattle, USA.

3. Hamamoto, M. \& Nakase, T. (1995). Ballistosporous yeasts found on the surface of plant materials collected in New Zealand. 1. Six new species in the genus Sporobolomyces. Antonie Leeuwenhoek 67, 151-171.

4. Komagata, K. \& Nakase, T. (1967). Reitoushokuhin no biseibutsu ni kansuru kenkyu. V. Shihan reitoushokuhin yori bunnri shita kobo no seijo (Microbiological studies on frozen foods. V. General properties of yeasts isolated from frozen foods) (in Japanese). Shokuhin Eiseigaku Zasshi 8, 53-57.

5. Nakase, T. \& Suzuki, M. (1985). Ballistospore-forming yeasts found on the surface of the Japanese rice plant, Oryza sativa L. J Gen Appl Microbiol 31, 457-474.

6. Nakase, T. \& Suzuki, M. (1986). Bullera megalospora, a new species of yeast forming large ballistospores isolated from dead leaves of Oryza sativa, Miscanthus sinensis and Sasa sp. in Japan. J Gen Appl Microbiol 32, 225-240.

7. Nakase, T. \& Takashima, M. (1993). A simple procedure for the high frequency isolation of new taxa of ballistosporous yeasts living on the surface of plants. RIKEN Rev 3, 33-34. 
8. Scott, D. B. \& van der Walt, J. P. (1970). Three new yeasts from South Africa insect sources. Antonie Leeuwenhoek 36, 389-396.

9. Suh, S.-O. \& Nakase, T. (1995). Phylogenetic analysis of the ballistosporous anamorphic genera Udeniomyces and Bullera, and related basidiomycetous yeasts, based on $18 \mathrm{~S}$ rDNA sequence. Microbiology 141, 901-906.

10. Suh, S.-O., Takashima, M. \& Nakase, T. (1996). Phylogenetic study of the anamorphic basidiomycetous yeasts Rhodotorula lactos $a$ and $R$. minuta, and related taxa based on $18 \mathrm{~S}$ ribosomal DNA sequences. J Gen Appl Microbiol 42, 1-6.

11. Suh, S.-O., Takashima, M., Hamamoto, M. \& Nakase, T. (1996). Molecular phylogeny of the ballistoconidium-forming anamorphic yeast genus Bullera and related taxa based on small subunit ribosomal DNA sequences. $J$ Gen Appl Microbiol 42, 501-509.

12. Suzuki, M. \& Nakase, T. (1988). The distribution of xylose in the cells of ballistosporous yeasts - application of high performance liquid chromatography without derivatization to the analysis of xylose in whole cell hydrolysates. $J$ Gen Appl Microbiol 34, 95-103.
13. Tamaoka, J. \& Komagata, K. (1984). Determination of DNA base composition by reversed-phase high-performance liquid chromatography. FEMS Microbiol Lett 25, 125-128.

14. Thompson, J. D., Higgins, D. G. \& Gibson, T. J. (1994). CLUSTAL $\mathrm{W}$ : Improving the sensitivity of progressive multiple sequence alignment through sequence weighting, position-specific gap penalties and weight matrix choice. Nucleic Acids Res 22, 4673-4680.

15. van der Walt, J. P. \& Yarrow, D. (1984). Methods for isolation, maintenance, classification and identification of yeasts. In The Yeasts, a Taxonomic Study, 3rd edn, pp. 45-104. Edited by N. J. W. Kreger-van Rij. Amsterdam: Elsevier.

16. Yamada, Y. \& Banno, I. (1984). Fellomyces, a new anamorphic yeast genus for the Q10-equipped organisms whose conidium is freed by an end-break in the sterigma. $J$ Gen Appl Microbiol 30, 523-525.

17. Yamada, Y. \& Kondo, K. (1973). Coenzyme Q system in the classification of the yeast genera Rhodotorula and Cryptococcus and the yeast-like genera Sporobolomyces and Rhodosporidium. J Gen Appl Microbiol 19, 59-77. 